\title{
Pathophysiology and Diagnostic Evaluation of Occupational Asthma from Exposure to Wood Dust and Diisocyanates in the Wood Processing Employees: A Preliminary Study
}

\author{
Eko Prasetyo ${ }^{1,2}$, Anies Anies $^{3 *}$, Nyoman Suci Widyastiti ${ }^{3}$, Suhartono Suhartono ${ }^{4}$ \\ ${ }^{1}$ Doctoral Study Program of Medical/Health Sciences, Faculty of Medicine, Diponegoro University, Semarang, Indonesia; \\ ${ }^{2}$ Public Health Study Program, STIKES Cendekia Utama Kudus, Kudus, Indonesia; ${ }^{3}$ Faculty of Medicine, Diponegoro University, \\ Semarang, Indonesia; ${ }^{4}$ Faculty of Public Health, Diponegoro University, Semarang, Indonesia
}

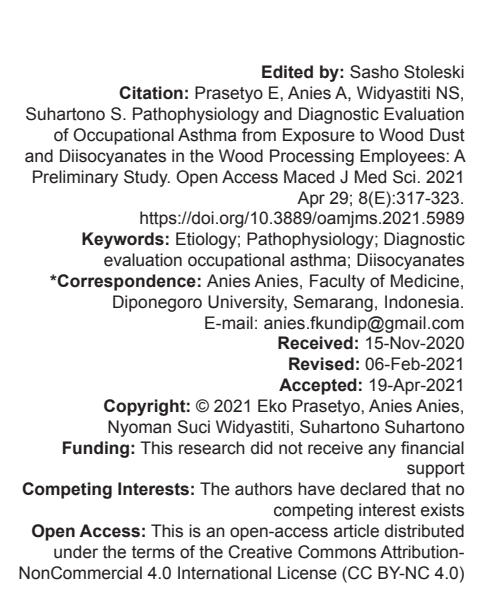

\begin{abstract}
AIM: This study is a preliminary study to analyze the etiology and pathophysiology of exposure to wood dust and diisocyanates in the wood processing industry in Jepara, Central Java, Indonesia. This study also provides a diagnostic evaluation of occupational asthma (OA) for ongoing exposure.

METHODS: The research method was carried out with a systematic review of various previous findings and with a preliminary study of workers in the processing industry in Jepara, Indonesia.

RESULTS: The results show that from a sample of 32 respondents who have been carried out in a wood processing factory in Jepara, it shows that the suspect OA in sanding workers by hand is $75 \%$, with the distribution of signs and symptoms: Chest tightness and pain (90\%); cough (53\%); shortness of breath (50\%); and wheezing (2\%). From the signs and symptoms felt, workers felt a continuous increase (progressivity) of OA by $75 \%$.

CONCLUSION: Theoretically, this preliminary study is useful to provide information about exposure to wood dust and diisocyanates as a risk factor for OA, especially among workers in the wood industry.
\end{abstract}

\section{Introduction}

Occupational asthma $(\mathrm{OA})$ is a form of asthma that is caused by known irritant agents that are attached to the work process [1]. OA is defined as a disease characterized by varying air flow limitations and/or airway hyper-responsiveness caused by working environmental conditions, not by stimuli outside the workplace. OA is only caused by allergens or allergens from the workplace or certain work environment conditions that stimulate asthma attack [2]. OA describes asthma that is caused by exposure to substances, which is precisely defined as being in the work environment. Although figures vary from country to country and are difficult to determine, it is estimated that $5-15 \%$ of asthma, newly diagnosed in working adults is due to occupational (or workplace) exposure [2]. OA prevalence estimates have been assessed in the previous studies. Workplace studies with exposure to certain substances have reported prevalence of OA ranging from $3 \%$ to $54 \%$. This has an impact on decreasing work productivity [3].
Research that examines the relationship between exposure to wood dust and diisocyanates with the incidence of $\mathrm{OA}$, among others, has been conducted by Algranti et al. [4], Sripaiboonkij et al. [5], Carlsten et al. [6], Ratnasingam et al. [7], Pollaris et al. [8]. Furthermore, Algranti et al. [4], Sripaiboonkij et al. [5], Carlsten et al. [6], Ratnasingam et al. [7], examined the aspects of the research design, which was carried out with a cross-sectional design, while this study was conducted with a case-control design. Furthermore, the subject aspect of the study [8] was carried out on animals (rats), while this research was carried out on human subjects.

This study is a preliminary study to analyze the etiology and pathophysiology of exposure to wood dust and diisocyanates in the wood processing industry in Jepara, Central Java, Indonesia. This study also provides a diagnostic evaluation of $\mathrm{OA}$ for ongoing exposure. Theoretically, this preliminary study is useful to provide information about exposure to wood dust and diisocyanates as a risk factor for OA, especially among workers in the wood industry. 


\section{Research Methods}

Conceptually, this study is a preliminary study to analyze the etiology and pathophysiology of exposure to wood dust and diisocyanates in the wood processing industry in Jepara, Central Java, Indonesia. The preliminary study specifically explores the issues associated with the empirical examination carried out at a later stage, by reviewing and evaluating the proposed propositions. In general, a preliminary study is used to identify the main features that will be addressed in the field research process at a later stage.

In general, this study specifically identifies and analyzes risk factors for exposure to wood dust and diisocyanates for OA by taking into account dust levels, diamine levels, levels of malondialdehyde (MDA), and levels of GPx3; on workers in the wood industry. In particular, the review in this study focuses on the etiology, pathophysiology, and diagnostic evaluation of sustained exposure to wood dust and diisocyanates in a wood processing company in Jepara, Indonesia. In wood processing activities, apart from workers being exposed to wood dust in the process of sawing and sanding wood, they are also exposed to diisocyanate in the spraying/painting process in the wood industry. In Presidential Decree number 7 of 2019 concerning occupational diseases, it is stated that wood dust and diisocyanates are irritants that can cause OA. Irritant substances will cause cell damage resulting in oxidative stress processes and the reactive oxygen species (ROS) mechanism, therefore, it is necessary to study several important OA biomarker indicators (AAK) from exposure to irritant substances such as diamine oxidase, MDA, and glutathione. This preliminary study used a sample of 32 worker respondents in the sanding department at PT. Kota Jati Furindo Jepara. Percentage analysis is used to identify symptoms and signs with suspected OA.

\section{Results}

\section{Demographic characteristics of respondents with $O A$}

$\mathrm{OA}$ is a disease characterized by impaired breath flow and bronchial hyperactivity that occurs due to conditions in the work environment and does not occur on stimuli outside the workplace. The diagnosis of OA must include a diagnosis of asthma and there must be a relationship with occupational exposure to materials [9].

The classification of asthma at work according to the American College of Chest Physicians is asthma due to work and asthma that is exacerbated at work [10].
OA is asthma caused by exposure to substances in the workplace, divided into two types depending on the presence or absence of a latent period, OA with a latent period, namely, asthma that occurs through an immunological mechanism. In this group, there is a latent period, namely, the period from the beginning of exposure until symptoms develop. Usually, there are people who have become sensitized, who when exposed to these substances again will cause asthma. OA without a latent period is asthma that occurs after exposure to high levels of workplace materials and is not closely related to immunological mechanisms. Symptoms like this are known as irritant-induced asthma or reactive airways dysfunction syndrome (RADS). RADS is defined as asthma that occurs within $24 \mathrm{~h}$ after one exposure to high concentrations of irritants such as gases or fumes that persist for at least 3 months.

Furthermore, asthma is exacerbated at work. Patients who have had asthma before or have received asthma therapy at least 2 years are more susceptible to substance exposure in workplace. For employees who already had asthma before working, 15\% will worsen due to exposure to substances/factors in the work environment. Descriptive analysis as in Table 1 shows that most of the respondents' ages are 23-38 years $(56.25 \%)$, with the female gender $(78.1 \%)$ and the work period of $1-10$ years $(84.38 \%)$.

Table 1: Frequency distribution of demographic characteristics of respondents

\begin{tabular}{lll}
\hline Variable & Frequency $(\mathrm{f})$ & Percentage $(\%)$ \\
\hline Age & & \\
23-38 & 18 & 56.25 \\
39-58 & 14 & 43.75 \\
Gender & & \\
$\quad$ Male & 7 & 21.9 \\
Female & 25 & 78.1 \\
Work experience & & \\
1-10 years & 27 & 84.38 \\
11-20 years & 5 & 15.62 \\
\hline
\end{tabular}

\section{Etiology of asthma due to work}

It is known that more than 250 substances or substances can cause OA. Exposure to particles inhaled in the workplace is one of the causes of OA. The severity of the disturbance depends on the intensity and duration of exposure to the inhaled material. Besides that, the particle size and concentration of dust in the air also determine the progression of respiratory disorders. Substances or substances that can cause OA can be grouped into two groups [11].

First, the substances cause asthma due to work through immunological mechanisms. This is the largest incidence of OA, which is $>90 \%$ of cases. Asthma causing substances through this immunological mechanism are differentiated into immunoglobulin $E$ ( $\lg E)$ dependent and $\lg E$ independent.

Second, the substances cause asthma due to work through non-immunological mechanisms. OA 
through no immunological mechanisms usually occurs without a latency period after exposure to substances that do not induce sensitization. Substances that can cause asthma like this include diisocyanates, formaldehyde, sulfur dioxide, and hydrofluoric acid, hydrocarbons, fumigating acid, ammonia, acetic acid, cadmium, and mercury. Formaldehyde at high concentrations is an irritant, but at low concentrations, it is a sensitizing agent that is widely used in the hospital and furniture industry. In a study of 230 workers who were exposed to formaldehyde, 12 people who suffered from OA have long been reported to have occurred in workers at an aluminum smelter known as potroom asthma [9]. Workers in this place are exposed to many particles and irritant gases such as sulfur dioxide, hydrofluoric acid, and hydrocarbons. At present, it is not known which substances most predominantly cause OA. It is only known that the case of RADS in potroom asthma occurred after workers was exposed to/inhaled air with high concentrations of aluminum and other substances. It is suspected that the aluminum reacts with hydrochloric acid and chlorine to form halide salts which make aluminum an irritating substance to the airways. The latent period from exposure to the onset of symptoms varies from 1 week to 10 years. Potroom asthma is reported more frequently in Australia and Norway than in North America [10].

\section{Pathophysiology of OA}

High-molecular-weight agents act as complete antigens and induce the production of specific IgE antibodies, whereas low-molecularweight (LMW) agents are those where workers are exposed to inducing specific $\lg E$ antibodies that may act as hapten and bind to proteins to form functional antigens. Histamine, prostaglandins, and cysteine leukotriene are released by mast cells after IgE cross-bridging by antigens, after antigen presentation by dendritic cells, $T$ lymphocytes can differentiate into several subtypes of effector cells. Antigen-activated CD4 cells can differentiate into cells with different functional properties provided by the pattern of secreted cytokines. Type 1 helper $\mathrm{T}$ (Th1) produces interferon- $\gamma$ and interleukin-2. Type 2 helper T cells (Th2) secrete cytokines such as inocleukins-4, -5 , and -13 ; activate cell $B$; and promoting $\mathrm{IgE}$ synthesis, mast cell recruitment, and eosinophilia. CD8 + cells also release interleukin-2 and interferon- $\gamma$ and correlate with increased disease severity and eosinophilia inflammation. Innate natural killer cells can also release interleukin-13 in response to cell damage products. There is evidence that some LMW agents, such as diisocyanates, can stimulate innate human immune responses by regulating immune pattern recognition receptors from monocytes and increasing macrophages that regulate trade in monocytes and macrophages (e.g., inhibiting factors for the migration of macrophages and protein monocytes chemoattractant 1). Further interleukin release includes interleukin-1 and -15 .

Airway epithelial injury tends to play a central role in the pathogenesis of irritant-induced asthma. Oxidative stress tends to be one of the mechanisms that cause epithelial damage. The stimulation of irritation is likely to result in the release of ROS by the epithelium. In addition, there may be an increase in neuropeptides from the nerve terminals, leading to neurogenic inflammation with the release of substance $P$ and neurokinins.

Sophorol reductase (SOR) is the main metabolite produced by the reduction of one electron of oxygen $\left(\mathrm{O}^{2}\right)$ from metabolism and chemical reactions in the body, which is a strong oxidant. Some oxidants are free radicals, and their activity can be suppressed by antioxidant compounds. Oxidative stress occurs when the resulting SOR is greater than what can be suppressed by cell defense mechanisms [13] (Figure 1).

The emergence of SOR in infection has the potential to cause oxidative damage in the form of lysis of all cell membranes and body tissues containing lipids including erythrocytes which have two layers composed of two solid phospholipid molecules. The reactivity of SOR results in the molecular structure of the cell membrane comprising cholesterol, phospholipids, and glycolipids (both of which contain unsaturated fatty acids) and DNA is very sensitive to hydroxyl radicals so that cell damage will occur and many peroxy fatty acid radicals are formed [13].

Lipid oxidation events in erythrocytes result in lysis or what is commonly known as hemolysis. Furthermore, the release of MDA (malondialdehyde) will result in cell damage [14].

Based on Table 2, it is known that the suspected incidence of $\mathrm{OA}$ is $75 \%$, with the distribution of signs and symptoms: Chest tightness and pain (90\%); coughing frequently (53\%); shortness of breath $(50 \%)$; and wheezing $(6 \%)$.

Table 2: Frequency distribution of respondents based on signs and symptoms of occupational asthma

\begin{tabular}{lcc}
\hline Variable & Frequency (f) & Percentage (\%) \\
\hline Cough & 15 & \\
$\quad$ No & 17 & 46.9 \\
$\quad$ Yes & & 53.1 \\
Out of breath & 16 & 50.00 \\
$\quad$ No & 16 & 50.00 \\
$\quad$ Yes & & \\
Chest tightness and pain & 3 & 9.40 \\
$\quad$ No & 29 & 90.60 \\
$\quad$ Yes & 30 & \\
Wheezing & 2 & 93.80 \\
$\quad$ No & 2 & 6.20 \\
$\quad$ Yes & 8 & 25.00 \\
Symptoms continue to increase (progressive) & & 75.00 \\
$\quad$ No & 24 & 25.00 \\
$\quad$ Yes & & 75.00 \\
Occupational asthma & 8 & \\
$\quad$ Non-occupational asthma & 24 & \\
$\quad$ Occupational asthma & & \\
\hline
\end{tabular}




\section{Diagnostic Evaluation of OA with Continuous Exposure}

One of the occupational lung diseases, namely, $\mathrm{OA}$, is an occupational disease that occurs most frequently in the world of work. Although figures vary from country to country and are difficult to determine, it is estimated that $5-15 \%$ of asthma, newly diagnosed in working adults, is due to occupational (or workplace) exposure [2]. OA prevalence estimates have been assessed in the previous studies. Workplace studies with exposure to certain substances have reported prevalence of OA ranging from $3 \%$ to $54 \%$. This has an impact on decreasing work productivity [3].

In wood processing activities, apart from workers being exposed to wood dust in the process of sawing and sanding wood, they are also exposed to diisocyanate in the spraying/painting process in the wood industry. In Presidential Decree number 7 of 2019 concerning occupational diseases, it is stated that wood dust and diisocyanates are irritant substances that can cause OA. The irritant material will cause cell damage resulting in an oxidative stress process and the ROS mechanism. It is necessary to study several important biomarker indicators of OA from exposure to irritants such as diamine oxidase, MDA, and glutathione.

A preliminary study of a sample of 32 respondents that have been carried out at PT. Kota Jati Furindo Jepara shows that the suspect OA in the hand sanding section is $75 \%$, with the distribution of signs and symptoms: Chest tightness and pain (90\%); coughing frequently (53\%); shortness of breath $(50 \%)$ and wheezing (6\%). From the signs and symptoms felt, workers felt a continuous increase (progressivity) of OA by $75 \%$.

The past studies have shown that organic diisocyanates are a significant occupational health problem. Diisocyanate is respiratory and skin sensitization which is the main cause of OA [15]. Diisocyanates include hexamethylene diisocyanate (HDI), toluene diisocyanate (TDI), isophorone diisocyanate (IPDI), and methylene-diphenyl diisocyanate (MDI) in reducing the order of volatility. HDI and IPDI are used for varnishes, coatings, and twopack spray paints used in motor vehicle repair. TDI and MDI are used for flexible and rigid polyurethane foam, floor coverings, and adhesives. These various uses mean that there are thousands of workers potentially exposed to isocyanates [16] (Figure 2).

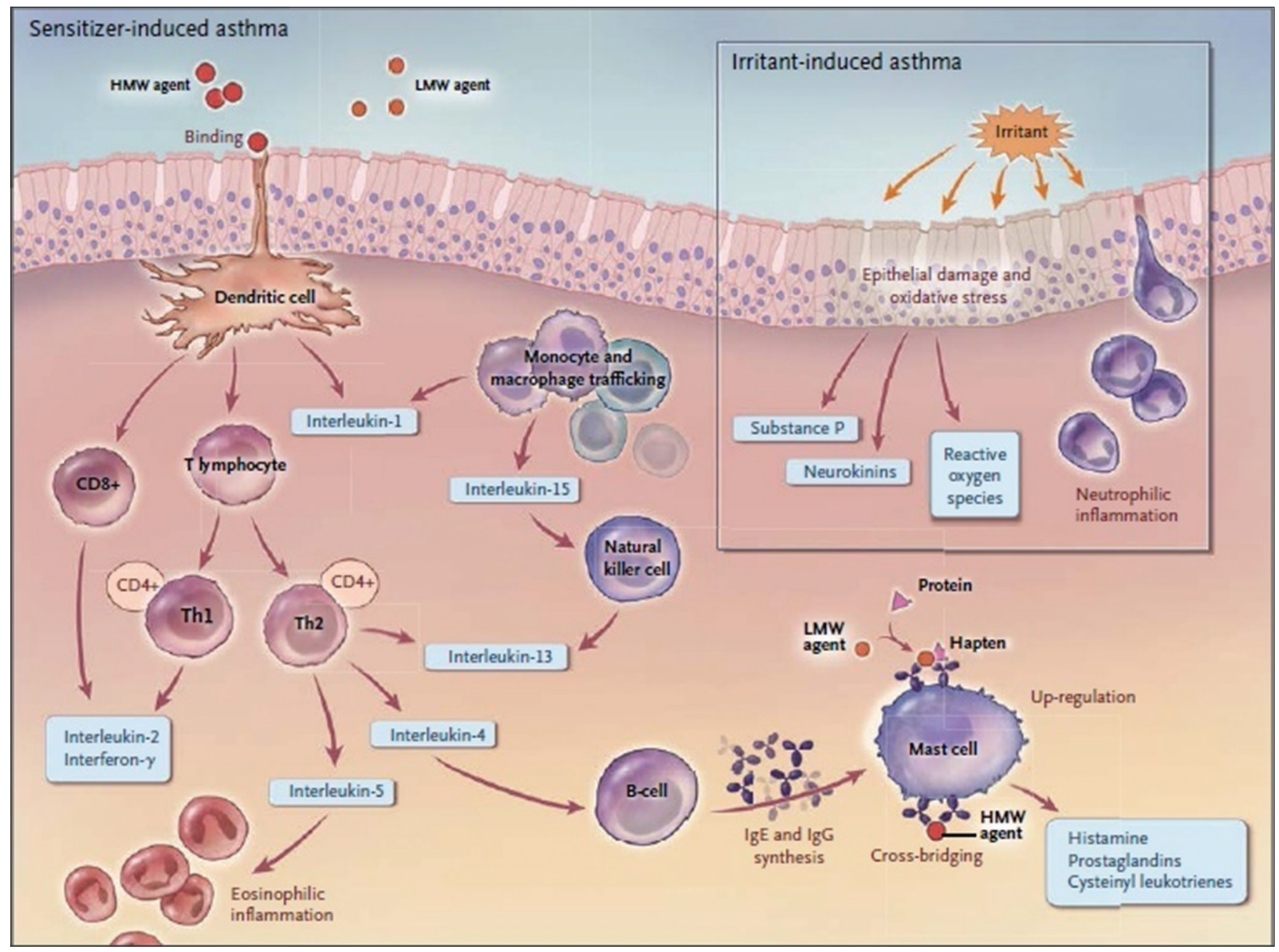

Figure 1: Pathophysiology of occupational asthma (mechanisms involved in sensitizer-induced asthma and irritant-induced asthma) 


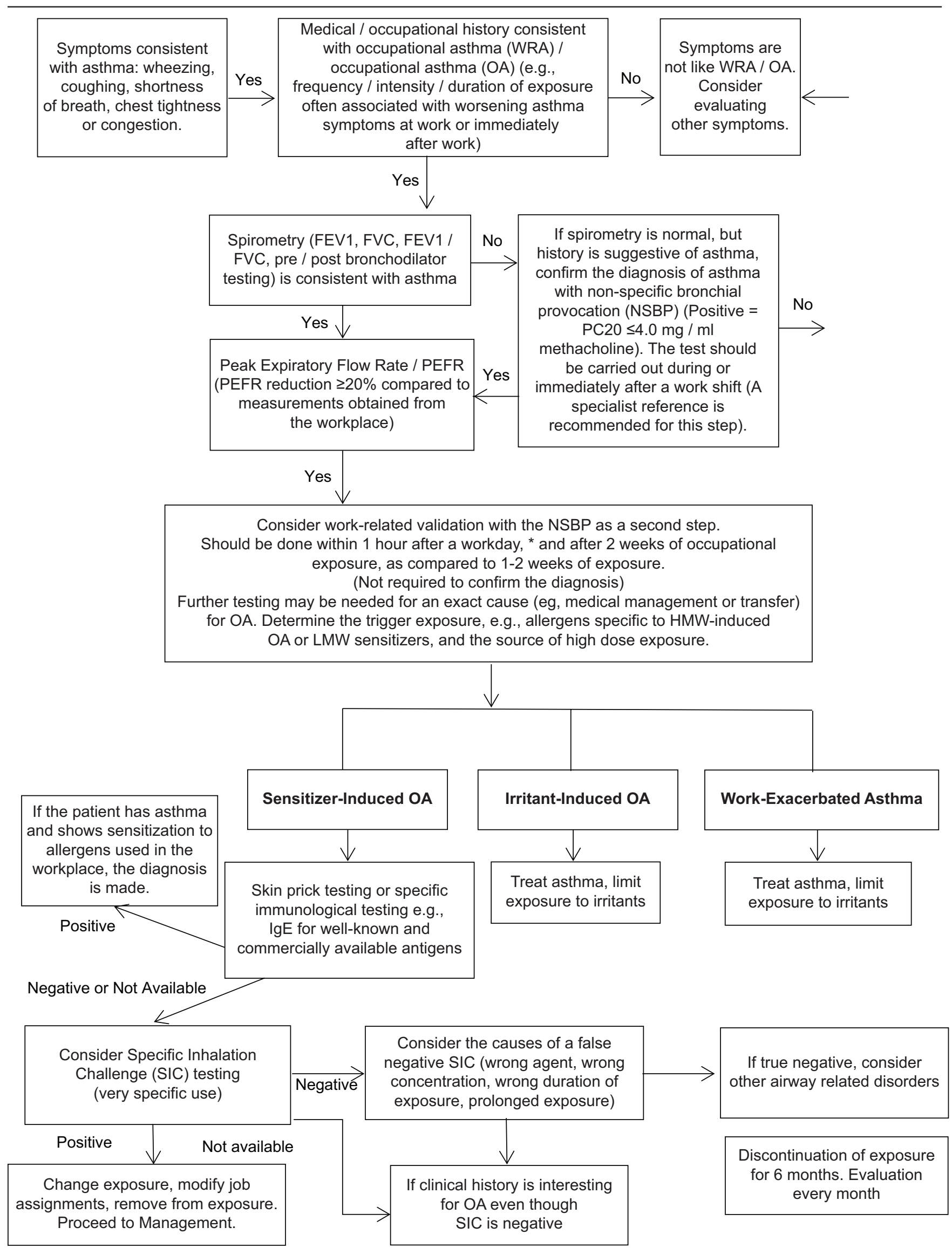

Source: [17]

Figure 2. Diagnostic evaluation of occupational asthma

Based on Table 3, it is known that the proportion of respondents who experience signs and symptoms of cough is greater in people with $\mathrm{OA}(82.4 \%)$ than those who do not suffer from OA $(17.6 \%)$, the proportion of 
respondents who experience signs and symptoms of shortness of breath is greater. In patients with $\mathrm{OA}$ $(100 \%)$ compared to those without OA $(0 \%)$, then the proportion of respondents who experienced signs and symptoms of chest tightness accompanied by pain was greater in patients with OA $(82.8 \%)$ than those without OA $(17.2 \%)$ and the proportion of respondents who experienced signs and symptoms of wheezing was greater in patients with OA $(100 \%)$ than those without $\mathrm{OA}(0 \%)$.

Table 3: The relationship between signs and symptoms with occupational asthma (OA) incidence

\begin{tabular}{|c|c|c|c|c|}
\hline Variable & Non OA & $\mathrm{OA}$ & OR $(95 \% \mathrm{Cl})$ & $p$-value $e^{a}$ \\
\hline \multicolumn{5}{|l|}{ Cough } \\
\hline No & $5(33.3 \%)$ & $10(66.7 \%)$ & $2.33(0.45-12.09)$ & 0.53 \\
\hline Yes & $3(17.6 \%)$ & $14(82.4 \%)$ & & \\
\hline \multicolumn{5}{|c|}{ Out of breath } \\
\hline No & $8(50.0 \%)$ & $8(50.0 \%)$ & $0.5(0.30-0.81)$ & $0.004^{\star}$ \\
\hline Yes & $0(0 \%)$ & $16(100 \%)$ & & \\
\hline \multicolumn{5}{|c|}{ Chest pain and tightness } \\
\hline No & $3(100 \%)$ & $0(0 \%)$ & $5.8(2.61-12.87)$ & $0.014^{\star}$ \\
\hline Yes & $5(17.2 \%)$ & $24(82.8 \%)$ & & \\
\hline \multicolumn{5}{|c|}{ Wheezing } \\
\hline No & $8(26.7 \%)$ & $22(73.3 \%)$ & $0.73(0.59-0.91)$ & 1.0 \\
\hline Yes & $0(0 \%)$ & $2(100 \%)$ & & \\
\hline
\end{tabular}

The results of a preliminary study proved that there was a significant relationship between signs of chest tightness and pain with the incidence of $\mathrm{OA}$ ( $p 0.014<0.05 ;$ OR $=5.8 ; 95 \% \mathrm{Cl}=2.61-12.87$ ). Furthermore, it is also known that there is a relationship between the signs of shortness of breath and the incidence of OA ( $p 0.004<0.05)$. From the results of the preliminary study, this research proves that of the four signs and symptoms of OA in the work environment, the indicators of symptoms of chest tightness accompanied by pain and shortness of breath are indicators of signs and symptoms that often appear in workers who experience OA.

\section{Conclusion}

$\mathrm{OA}$ is a disease characterized by impaired breath flow and bronchial hyperactivity that occurs due to conditions in the work environment and does not occur on stimuli outside the workplace. The diagnosis of OA must include a diagnosis of asthma and there must be a relationship with occupational exposure to materials [9]. One of the occupational lung diseases, namely, OA, is an occupational disease that occurs most frequently in the world of work. Although figures vary from country to country and are difficult to determine, it is estimated that $5-15 \%$ of asthma, newly diagnosed in working adults, is due to occupational (or workplace) exposure [2]. OA prevalence estimates have been assessed in the previous studies. Workplace studies with exposure to certain substances have reported prevalence of OA ranging from $3 \%$ to $54 \%$. This has an impact on decreasing work productivity.
In wood processing activities, apart from workers being exposed to wood dust in the process of sawing and sanding wood, they are also exposed to diisocyanate in the spraying/painting process in the wood industry. In Presidential Decree number 7 of 2019 concerning occupational diseases, it is stated that wood dust and diisocyanates are irritant substances that can cause OA. The irritant material will cause cell damage resulting in an oxidative stress process and the ROS mechanism. It is necessary to study several important biomarker indicators of OA from exposure to irritants such as diamine oxidase, MDA, and glutathione. A preliminary study of a sample of 32 respondents that have been carried out at PT. Kota Jati Furindo Jepara shows that the suspect $\mathrm{OA}$ in the hand sanding section is $75 \%$, with the distribution of signs and symptoms: Chest tightness and pain (90\%); coughing frequently $(53 \%)$; shortness of breath $(50 \%)$; and wheezing $(6 \%)$. From the signs and symptoms felt, workers felt a continuous increase (progressivity) of OA by $75 \%$.

\section{References}

1. International Labour Organization. ILO List of Occupational Diseases. Geneva, Switzerland: ILO; 2010.

2. Anies. Kedokteran Okupasi; Berbagai Penyakit Akibat Kerja dan Upaya Penanggulangan dari Aspek Kedokteran. Yogyakarta: Ar-Ruzz Media; 2014.

3. Bernstein DI, Korbee L, Bernstein A, Scinto J, Herd ZL, Leonard I. Clinical aspects of allergic disease. J Allergy Clin Immunol. 1993;10:158-64.

4. Algranti E, Mendonça EM, Ali SA, Kokron CM, Raile V. Occupational asthma caused by Ipe (Tabebuia spp) dust. J Investig Allergol Clin Immunol. 2005;15(1):3. PMid:15864889

5. Sripaiboonkij P, Phanprasit W, Jaakkola MS. Respiratory and skin effects of exposure to wood dust from the rubber tree Hevea brasiliensis. Occup Environ Med. 2009;66(7):442-7. https://doi. org/10.1136/oem.2008.042150

PMid: 19188201

6. Carlsten C, Dybuncio A, Pui MM, Chan-Yeung M. Respiratory impairment and systemic inflammation in cedar asthmatics removed from exposure. PLoS One. 2013;8(2):e57166. https:// doi.org/10.1371/journal.pone.0057166

PMid:23468925

7. Ratnasingam J, loras F, Tadin I, Wai LT, Ramasamy G. Respitarory effect in woodworkers exposed to wood and wood coatings dust: A regional evaluation of South East Asian countries. J Appl Sci. 2014;14(15):1763-8. https://doi. org/10.3923/jas.2014.1763.1768

8. Pollaris L, Devos F, De Vooght V, Seys S, Nemery B, Hoet $\mathrm{PH}$, et al. Toluene diisocyanate and methylene diphenyl diisocyanate: Asthmatic response and cross-reactivity in a mouse model. Arch Toxicol. 2016;90(7):1709-17. https://doi. org/10.1007/s00204-015-1606-6 PMid:26468151

9. Alimudiarnis A. Diagnosis dan Penatalaksanaan Asma Akibat Kerja. Padang: Universitas Andalas; 2018.

10. Yeung C, Malo JL. Occupational asthma. N Engl J Med. 
2007;333(2):107-12.

11. Beckett WS. Occupational respiratory diseases. N Engl J Med. 2000;342(6):406-13.

PMid:10666432

12. Tarlo SM, Lemiere C. Occupational asthma. N Engl J Med. 2014;370(7):640-9. PMid:24521110

13. Dröge W. Free radicals in the physiological control of cell function. Physiol Rev. 2002;82(1):47-95.

PMid:11773609

14. Arkhaesi N. Kadar Malondialdehyde (MDA) Serum Sebagai Indikator Prognosis Keluaran Pada Sepsis Neonatorum.
Semarang: Universitas Diponegoro; 2008.

15. McDonald JC. Incidence by occupation and industry of acute work related respiratory diseases in the UK, 1992-2001. Occup Environ Med. 2005;62(12):836-42. https://doi.org/10.1136/ oem.2004.019489

PMid:16299091

16. Cocker J. Biological monitoring for isocyanates. Occup Med (Lond). 2007;57(6):391-3.

PMid: 17728308

17. Hegmann KT, Biggs JJ, Hughes MA, Jolly AT, Klees JE, Bohnker BK, et al. Contributors to the Occupational/WorkRelated Asthma Guideline; 2016. p. 154. 